Egyptian Journal of Rabbit Science, 28 (2): 311 -332 (2018)

\title{
EFFECT OF UNSATURATED FATTY ACIDS ON HORMONAL PROFILE, ANTIOXIDANT STATUS, SEMEN QUALITY AND REPRODUCTIVE PERFORMANCE IN AGING BUCK RABBITS
}

\author{
M.A. El-Sawy ${ }^{1}$, T.A. Sadaka ${ }^{1}$, and M.I. Shourrap ${ }^{2}$ \\ 1- Anim. Prod. Res. Instit., Agric. Res. Cent., Egypt \\ 2- Poult. Prod. Dep., Fac. of Agric., Ain Shams Uni., Cairo, Egypt. \\ elsawy1966@gmail.com
}

Twenty five aging V-lines buck rabbits, 24- month of age weighing at average $3230 \pm 41.7 \mathrm{~g}$ and 30 multiparous does aged 7 month at average body weight $3150 \pm 38.5 \mathrm{~g}$ were used. Bucks were randomly distributed to five equal groups for orally administered with 3 $\mathrm{ml}$ of different sources of refined vegetable oil/buck/daily, for seven consecutive weeks prior to semen collection as follows: group: 1 were given sterilized water and served as control $(C)$, group; 2 sesame oil (Ses), group: 3 linseed oil (Lin), group: 4 sunflower oil (Sun), group: 5 mixture oil (Mix) oil containing equal portions of Ses, Lin and Sun. Serum testosterone, follicles stimulating hormone (FSH), luteinizing hormone $(L H)$, prostaglandin $(P G F 2 \alpha)$, total antioxidant enzymes $(T A C)$ and malonylaldehayed (MAD), reaction time(RT) and semen quality were measured. Results revealed that as follows:

1- Concentrations of serum testosterone, FSH and LH were significantly $(P \leq 0.01)$ improved in treated groups compared with control group otherwise $P G F 2 \alpha$ recorded highest values in all treated groups.

2- Aging buck rabbits consumed either Lin or Mix oils recorded the best values of serum testosterone, FSH and LH hormones concentration.

3- All experimental treated groups represented significant $(P \leq 0.01)$ increase of $T A C$ and significant $(P \leq 0.01)$ reduction in $M A D$ compared with control.

4- Reaction time, advanced motility, ejaculate volume, sperm concentration, abnormal sperm, dead sperm, fertility rate and litter size at birth were statistically $(P \leq 0.01)$ improved for groups supplemented with Lin and Mix oils compared to the other treated groups and control. 
Conclusively, from these results it could be concluded that supplementing aging buck rabbits with Lin or Mix oils (rich source of n6 and n-3) for 7 consecutive weeks before mating or artificial insemination, had improved the reproductive performance, libido, antioxidant status and fertility traits.

Key words: Aging rabbit bucks, sexual hormones, semen quality, fertility traits.

Several studies on lipid metabolism have shown that alpha linolenic acid (ALA) (18:3 n-3) and linoleic acid (LA) (18:2 n-6) cannot be synthesized in the most mammals' species including rabbits and avian due to the lack of appropriate fatty acid desaturase enzymes (Vrablik and Watts, 2013) and consequently they must be supplied in the diet, therefore they are called essential fatty acids (EFA). However, Cherian (2013) reported that saturated fatty acids (SFA) and monounsaturated fatty acids (MUSFA) can be synthesized from simple precursors such as glucose or ketogenic amino acids in some mammal's species. Interestingly sufficient some dietary fats may have a role in maintaining and improving semen quality in animals. More of studies have shed light on the fundamental role of fatty acids principally polyunsaturated fatty acids (PUFAs) in sperm biology (Esmaeili et al., 2014).

Additionally, Laddha et al., (2012) reported that polyunsaturated fatty acids (PUFAs) are essential nutrients of importance several cellular functions in the body including legends for transcription factor, precursors of signal molecules and building blocks in all cells of the body. Wathes et al., (2007) reported that PUFAs such as n-3 and n- 6 are essential nutrients used to improve the reproductive performance for males and maintenance sperm membrane integrity, especially during cryopreservation. However, the dietary effect of PUFAs on lymphocyte stimulation is caused by increased competition of $n-3$ and n-6 FA on the binding sites of cyclooxygenase to synthesis prostaglandins and can modulate the formulation patterns of many key enzymes for steroid metabolism. There are a wide variety of fats that can be supplemented to the rations, plant based oils primarily extracted from seeds such as sunflower, linseed, sesame, cotton seed, soybean and olives, these vegetable oils are considered a rich source of essential PUFAs. It is well known that the semen volume, sperm concentration, as well as fertility and litter size at birth are affected by the age of the rabbit's buck. Since, these traits were increased over time and were observed in a higher value in mature bucks up to 24 months comparing to the oldest bucks (Miros and Mikhno, 1982). On the other hand, Plas 
et al., (2000) recorded that the increase the expectancy life males for has raised issues concerning the impact of aging on the endocrine system and male fertility and the relationship of spermatogenesis to changes with age in androgen production and testicular morphology, the influence of age on semen traits and chromosomal quality has an impact of paternal age and pregnancy outcome. Buck age has positive effect on sperm concentration, libido, semen volume, sperm motility and pH of semen (Luzi et al., 1996; Minelli et al., 1999 a and b). Nevertheless, characteristic age-related morphological testicular alterations have been described, such as decreased numbers of interstitial cells (Leyidg cells) paralleling decreased testosterone production, arteriosclerotic lesions, thickening and hernia-like protrusions of the basal membrane of the seminiferous tubules, and fibrotic thickening of the tunica albuginea. However, the health status, stress condition and aging of the animals can lower the conversion rate elongate and desaturate $\alpha$-linolenic acid efficiently (Bernardini et al., 1999) and increased production of reactive oxygen metabolites with aging is probably due to a physiological increase of the anabolic processes Herbert (1996). Otherwise, these alterations do not lead to significant differences in sperm-morphology, time of spermatozoa development or sperm function between young and elderly males (Plas et al., 2000).

Since semen quality plays an important role in great farm economic profit don the enhancement of conception rate and total yield number of animals born for each herd (Santos et al., 2008). Polyunsaturated fatty acids such as linoleic acid (LA, 18:2n-6), alpha-linolenic acid (ALA, C18:3, n-3), eicosapentaenoic acid (EPA, C20:5, n-3), and docosahexaenoic acid (DHA, C22:6, n-3) may object reproductive organs and modify reproductive functions and fertility (Thatcher and Staples, 2007).

Sperm mammals contain high concentration of PUFAs (Kelso et al., 1997) especially docosahexaenoic acid (DHA, C22:6, n-3) and docosapentaenoic acid (DPA, C22:5, n-3) (Wathes et al., 2007). It has been known that PUFAs n-3 and n- 6 are essential for the reproductive activity (representing about $30-50 \%$ of total fatty acids) are in the membrane cell of spermatozoa (Poulos et al., 1973) for contributing fluids regulation fluidity and acrosome responsiveness. Castellini et al., (2003) which affect the ability of the plasma membrane to accommodate the flagella motion of the sperm.

Therefore, the objective of this study was investigate the effect of orally administration of polyunsaturated fatty acids (different sources of omega-3 and omega-6) on reproductive hormones, antioxidant status and semen quality in aging male rabbits. 


\section{MATERIALS AND METHODS}

\section{Housing and management:}

The present study was carried out at a private rabbit farm at Qaluobia Governorate during season from 2017-2018 (ambient temperature ranged from 19 to $27^{\circ} \mathrm{C}$ while, relative humidity ranged from 43 to $54 \%$ and light photo period $16 \mathrm{hr}$ light : $8 \mathrm{hr}$ dark.

Twenty five V-line buck rabbits aging, 24 months age with an average weight $3230 \pm 41.7 \mathrm{~g}$ and 30 multiparous does aged 7 months (not treated) with average weight $3150 \pm 38.5 \mathrm{~g}$ were used for the present study. Animals were housed in clean, separate wire-floor metal cages and maintained under standard laboratory conditions. Bucks were allowed to a standard pelleted diet (Table 1). Feed and water were available ad libitum. All rabbits were kept under the same managerial condition, healthy and clinically free of external and internal parasites.

Polyunsaturated fatty acid composition of sesame, linseed and sunflower oils are presented in Table 2. Polyunsaturated fatty acid composition of sesame, linseed and sunflower oils are based on references by Hassan, (2012)1, El-Prollosy, (2012) ${ }^{2}$ and Ismaill and Arafat, (2014) respectively. Mixture oil, the ratio of $\omega 6 / \omega 3$ calculated according to previous analysis recorded 1.4:1

\section{Experimental design:}

Current experiment was divided into two experiments:

First experiment:

Bucks were administrated orally $3 \mathrm{ml}$ oils daily for each male as a preliminary phase for sequence seven weeks before semen collection (spermatogenesis period 43.6-51.8 days; as reported by Swierstra and Foote, (1965). Rabbit bucks were divided into five equal treatment groups (5 bucks / each) as follows:

Group 1: $3 \mathrm{ml}$ sterilized water was given orally and served as control group (C), Group 2: Orally $3 \mathrm{ml}$ of Sesame oil* (Ses), Group 3: Orally $3 \mathrm{ml}$ of Linseed oil* (Lin), Group 4: Orally $3 \mathrm{ml}$ of Sunflower oil* (Sun),

Group5: Orally $3 \mathrm{ml}$ of Mixture oils** (Mix),

*Mixture oils. Contains equal portion of Ses, Lin and Sun oils. 
Table1. Composition and determined analysis (on a drymatter basis) of the experimental commercial diet used

\begin{tabular}{|c|c|}
\hline Ingredients & $\%$ \\
\hline Yellow corn & 6.22 \\
\hline Soybean meal, $44 \%$ & 22.33 \\
\hline Wheat bran & 23.33 \\
\hline Barley & 15.00 \\
\hline Alfalfa hay & 30.12 \\
\hline Ground limestone & 1.00 \\
\hline Dicalcium Phosphate & 1.20 \\
\hline Common salt & 0.50 \\
\hline Vit. + min. premix ${ }^{*}$ & 0.30 \\
\hline Total & 100 \\
\hline \multicolumn{2}{|l|}{ Calculated analysis $^{* * *}$} \\
\hline Crude protein, \% & 18.8 \\
\hline Crude fiber, \% & 13.0 \\
\hline Ether extract, \% & 3.0 \\
\hline Digestible energy (kcal $/ \mathrm{kg}$ diet) & 2680 \\
\hline n-6 PUFAs $\%$ & 0.3 \\
\hline n-3 PUFAs $\%$ & 1.03 \\
\hline$n-6 / n-3$ ratio & $0.3: 1$ \\
\hline \multicolumn{2}{|l|}{ Determined analysis $(\mathrm{g} / \mathrm{kg})$} \\
\hline Dry matter & 902.4 \\
\hline Organic matter & 912.1 \\
\hline Crude protein & 172.4 \\
\hline Crude fiber & 138.5 \\
\hline Ether extract & 26.2 \\
\hline Nitrogen-free extract & 575.0 \\
\hline Ash & 87.9 \\
\hline \multicolumn{2}{|l|}{ Cell wall constituents $(\mathrm{g} / \mathrm{kg})$} \\
\hline Neutral detergent fiber (NDF) & 331.1 \\
\hline Acid detergent fiber (ADF) & 160.9 \\
\hline Hemicellulose & 170.2 \\
\hline
\end{tabular}

Each 3 kg of premix contains: Vit. A: 12,000,000 IU; Vit. D3: 3,000,000 IU; Vit. E:10.0 mg; Vit. K3: $3.0 \mathrm{mg}$; Vit. B1: $200 \mathrm{mg}$ : Vit. B2: $5.0 \mathrm{mg}$ Vit. B6: $3.0 \mathrm{mg}$ : Vit. B12: $15.0 \mathrm{mg}$; Biotin: $50.0 \mathrm{mg}$; Folic acid: $1.0 \mathrm{mg}$; Nicotinic acid: $35.0 \mathrm{mg}$ : Pantothenic acid: $10.0 \mathrm{mg}$; Mn: $80 \mathrm{~g}$; $\mathrm{Cu}$ : $8.8 \mathrm{~g} ; \mathrm{Zn}: 70 \mathrm{~g} ; \mathrm{Fe}: 35 \mathrm{~g}$; I: $1 \mathrm{~g}$; Co: $0.15 \mathrm{~g}$ and Se: $0.3 \mathrm{~g}$. 
Table 2. Polyunsaturated fatty acid analysis of sesame, linseed and sunflower oils

\begin{tabular}{|c|c|c|c|c|c|c|}
\hline \multirow{2}{*}{ Type of oils } & \multicolumn{7}{|c|}{ Mean Fatty acids \% } \\
\cline { 2 - 7 } & $\begin{array}{c}\text { Palmetic } \\
16: 0\end{array}$ & $\begin{array}{c}\text { Stearic } \\
18: 0\end{array}$ & $\begin{array}{c}\text { Oleic } \\
18: 1\end{array}$ & $\begin{array}{c}\text { Linoleic } \\
(\omega 6) 18: 2\end{array}$ & $\begin{array}{c}\text { Linolenic } \\
(\omega 3) 18: 3\end{array}$ & $\begin{array}{c}w 6 / \omega 3 \\
\text { Ratio }\end{array}$ \\
\hline Sesame oil (Ses) & 8.47 & 5.53 & 41.63 & 42.77 & 0.42 & $101: 1$ \\
\hline Linseed oil (Lin) $^{\mathbf{1}}$ & 5.51 & 3.8 & 13.5 & 14.8 & 62.1 & $0.24: 1$ \\
\hline Sunflower (Sun) & 6.65 & 4.97 & 52.83 & 33.15 & 0.51 & $65: 1$ \\
\hline
\end{tabular}

\section{Second experiment:}

Rabbit does were randomly assigned to five equal treatment groups (6 does / each) and inseminated at the end of the experiment (for four consecutive mating) with semen samples from bucks in each group of C, Ses, Lin, Sun and Mix $\left(30 \times 10^{6}\right.$ fertile sperm $/ 0.5 \mathrm{ml}$ as average insemination portion). The insemination procedure was performed as described by Adams (1981). All rabbit does were injected with $20 \mu \mathrm{g}$ gonadotropin-releasing hormone analogue (GnRH, Receptal, Intervet Lab) to induce ovulation immediately after insemination as described by Lopez and Alvarino, (2000). Kindling rate and litter size at birth were recorded according to IRRG (2005).

\section{Blood biochemical constituents :}

At the end of the experimental bucks blood samples $(3 \mathrm{ml})$ were withdrawn at morning from marginal ear vein for each treatment group before access feed and water. Blood samples were centrifuged at 3000 r.p.m for 15 min to obtain a clear serum samples and stored at $-20{ }^{\circ} \mathrm{C}$ until analysis the following hormones.

\section{Measurement of serum Testosterone, LH and FSH hormones and PGF2a:}

Total serum concentration of testosterone (T) was assayed using a double-antibody RIA kit (Immunotech Beckman Coulter Co., USA). Serum concentrations of FSH and LH hormones were assayed in duplicated samples for direct quantitative determination of Luteinizing and follicle stimulating hormone by enzyme immunoassay in serum (ALPCO 2013; Version: 9.1,8/9/2013). Prostaglandin F2 $\alpha$ (PGF2 $\alpha$ ) hormone-like was measured using a PG ELISA kit (the Sensitivity: $50 \%$ B/B0:52 pg/ml) Cayman Chemicals, Ann Arbor, MI, USA. 


\section{Measurement of serum antioxidant:}

Biochemical analyses of serum TAC and MAD were determined using commercially available kits methods using spectrophotometers, (GNW-Model: SM-721) according to Ippoushi et al., (2005).

\section{Reaction time (RT):}

The time in seconds it took for the rabbit bucks to sniff, groom and mount the female was recorded with a stop-watch as described by Chibundu (2005).

\section{Semen collection and analysis:}

At the end of the experiment, semen was artificially collected twice per week for 6 weeks by means of the artificial vagina as described by Smith and Mayer, (1955). Advanced sperm motility, sperm abnormality, and sperm cell concentration were evaluated. Semen was diluted (1:8 ratio) in a Trisbuffered extender and incubated for $30 \mathrm{~min}$ in a warm water bath at $37^{\circ} \mathrm{C}$. The percentages of motile spermatozoa were evaluated from three samples of the diluted spermatozoa placed under a cover slide in the center of a prewarmed $\left(37^{\circ} \mathrm{C}\right)$ slide and transferred to a heated microscope stage set at $37^{\circ}$ C. The evaluation was subjectively assessed using phase contrast microscopy (X 200 magnification). The motile spermatozoa was recorded on a five multiple percentage of 0 to 100 where 0 is absence of movement and 100 is when all motile spermatozoa are showing progressive head rectilinear linear motility. The proportions of spermatozoa with abnormal morphology measured using Giemsa's stain and examined under a phase contrast microscope at the magnification of $1000 \mathrm{X}$. Morphological abnormalities included head, midpiece (excluding distal cytoplasmic droplets) and tail defects. Sperm cell concentration was evaluated in improved Neubauer haemocytometer slide, after extending (1:400, v/v) an aliquot of semen with $0.3 \%$ formaldehyde in phosphate-buffered saline with few drops of eosin stain according to Smith and Mayer, (1955) and Correa and Zavos, (1996).

\section{Statistical analysis:}

All data were subjected to analysis of variance as described of SAS Program (SAS, 2002). The significant means differences among groups were separated by Duncan's multiple rang test (Duncan, 1955). 


\section{RESULTS AND DISCUSSION}

\section{Reproductive hormones and antioxidant enzymes:}

Table 3 shows the effect of different polyunsaturated oils administration as source of (n-3 and n-6) for aging bucks on Testosterone, FSH, LH, PGF2 $\alpha$, TAC and MAD concentrations. The obtained data revealed that the testosterone hormone concentration for all treated groups was significant $(\mathrm{P} \leq 0.01)$ higher compared to the control group. However the Lin and Mix oils groups recorded a highest testosterone value 5.13 and $5.2 \mathrm{ng} / \mathrm{ml}$, respectively than the Sun and Ses oils groups which recorded 4.64 and $4.52 \mathrm{ng} / \mathrm{ml}$, respectively. Otherwise that there were no statistical differences between Ses and Sun oils groups with respect to testosterone hormone. With respect to FSH and LH hormones, data recorded that there were no significant differences either between rabbit groups supplied with Lin and Mix or between the groups supplied with Ses or Sun oils. On the other hand, FSH and $\mathrm{LH}$ hormones were significantly $(\mathrm{P} \leq 0.01)$ increased in blood bucks that received either Lin or Mix oils in comparison with the other two treatments groups of Ses or Sun oils and the control group which exhibited the lowest concentration of FSH and LH hormones.

Moreover data of Table 3 showed that all groups of rabbit bucks received oil source either groups separated or combined represented significant $(\mathrm{P} \leq 0.01)$ increase of PGF2 $\alpha$ compared with those for control, while there were no statistical differences among the experimental treated groups. Date of the antioxidant (Table 3) revealed that the concentration of TAC enzyme was significantly $(\mathrm{P} \leq 0.01)$ increased for all treated groups supplemented with oils compared to control group, whereas MAD enzyme concentration represented opposite trend as significantly $(\mathrm{P} \leq 0.01)$ decreased for all groups supplemented with oils compared to control group.

Several studies showed that the role of polyunsaturated fatty acids such as linoleic acid (LA, 18:2n-6), alpha-linolenic acid (ALA, C18:3n-3), eicosapentaenoic acid (EPA, C20:5n-3), and docosahexaenoic acid (DHA, C22:5n-3) may target reproductive tissues and improved reproductive function and fertility (Thatcher and Staples, 2007) and Gurr et al., (2002) they reported that the two essential fatty acids(LA and ALA) can be converted in the liver to longer chain PUFAs by desaturation and elongation enzyme systems . 
Table 3. Effect of unsaturated fatty acids oils on serum testosterone, FSH,

$\mathrm{LH}, \mathrm{PGF}_{2} \alpha, \mathrm{TAC}$ and MAD for aging bucks of V-line rabbits

\begin{tabular}{|c|c|c|c|c|c|c|}
\hline Parameters & Control & Ses & Lin & Sun & Mix & $\begin{array}{c}\text { Sig. } \\
\text { test }\end{array}$ \\
\hline \multicolumn{7}{|c|}{ Orally 3 mL oil/buck/day } \\
\hline T (ng/mL) & $4.11^{\mathrm{c}}$ & $4.52^{\mathrm{b}}$ & $5.13^{\mathrm{a}}$ & $4.64^{\mathrm{b}}$ & $5.21^{\mathrm{a}}$ & \\
& \pm 2.19 & \pm 2.33 & \pm 3.82 & \pm 3.14 & \pm 2.36 & \\
\hline FSH (ng/mL) & $0.55^{\mathrm{c}}$ & $0.60^{\mathrm{b}}$ & $0.69^{\mathrm{a}}$ & $0.62^{\mathrm{b}}$ & $0.72^{\mathrm{a}}$ & \\
& \pm 0.46 & \pm 0.98 & \pm 1.01 & \pm 1.01 & \pm 1.06 & \\
\hline LH (ng/mL) & $1.44^{\mathrm{c}}$ & $1.64^{\mathrm{b}}$ & $1.96^{\mathrm{a}}$ & $1.73^{\mathrm{b}}$ & $2.03^{\mathrm{a}}$ & \\
& \pm 1.34 & \pm 1.42 & \pm 0.89 & \pm 1.98 & \pm 0.93 & \\
\hline PGF2 $\mathbf{( g / m L )}$ & $480.96^{\mathrm{b}}$ & $598.69^{\mathrm{a}}$ & $576.51^{\mathrm{a}}$ & $600.96^{\mathrm{a}}$ & $588.32^{\mathrm{a}}$ & \\
& \pm 2.15 & \pm 2.85 & \pm 2.48 & \pm 2.96 & \pm 2.67 & \\
\hline TAC (nmol/mL) & $2.02^{\mathrm{b}}$ & $2.79^{\mathrm{a}}$ & $2.75^{\mathrm{a}}$ & $2.71^{\mathrm{a}} \pm$ & $2.69^{\mathrm{a}}$ & \\
& \pm 0.04 & \pm 0.08 & \pm 0.04 & 0.07 & \pm 0.06 & \\
\hline MAD(nmol/mL) & $3.45^{\mathrm{a}}$ & $2.56^{\mathrm{b}}$ & $2.65^{\mathrm{b}}$ & $2.53^{\mathrm{b}}$ & $2.72^{\mathrm{b}}$ & \\
& \pm 0.03 & \pm 0.05 & \pm 006 & \pm 0.07 & \pm 0.04 & \\
\hline
\end{tabular}

a,b,c Means within the same row for each effect with different superscripts are significantly different $(\mathrm{P} \leq 0.05)$.

Ses=Sesame oil, Lin=Linseed oil, Sun=Sunflower oil, Mix=Mixture of Ses, Lin and Sun oils, $\mathrm{T}=$ Testosterone, $\mathrm{FSH}=$ follicle stimulating hormone, $\mathrm{LH}=$ Luteinizing hormone, PGF $2 \alpha=$ Prostaglandin, TAC $=$ Total antioxidant capacity, MAD=Malondialdehyde.

* $\quad \mathrm{P} \leq 0.05 * * \mathrm{P} \leq 0.01$

In males, activity of reproductive system involves the hypothalamicpituitary-testicular axis, which controls hormones involving testicular development and spermatogenesis. Surai et al., (2000) revealed that the dietary PUFAs effect on secretion of gonadotropin-releasing hormone $(\mathrm{GnRH}), \mathrm{FSH}$ and $\mathrm{LH}$ and the responsiveness of these cells to hormonal production.

Results are in agreement with that reported by Adibromadi et al., (2012) who mentioned that dietary soybean oil (high in C18:2 n-6) did not significantly affect the testosterone concentration.This indicated that Lin and Mix oils had an percentage of high n-3 PUFAs and had a positive influence on gonad development and when dietary DHA level increased, better gonad development could be observed. It is likely that the incorporation of n-3 PUFAs from these oils affected the testis development through its impact on hypothalamopituitarygonadal axis. Based on previous data, there has been a lot of evidence approving the relationship of this axis with the testis development in male via the activity of FSH and LH. 
Follicle stimulating hormone (FSH) is considered as the main mitogenic factor responsible for sertoli cell divisions and $\mathrm{LH}$ as main factor affecting differentiation and maturation of the leydig cell population (Almiron and Chemes, 1988). Esmaeil et al., (2015) showed that rams which received fish oil (n-3) had the total highest testosterone and PGF2 $\alpha$ concentrations in the blood compared with those fed sunflower oil. This finding indicated that fish oil (high in n-3 PUFAs) supplementation in diet possibly affected phospholipid composition in plasma membranes of the testes, altered the expression and affinity of gonadotropin receptors and influenced the rate of testosterone synthesis.

Contrariwise, Juma et al., (2011) stated that the increase of FSH and LH levels in rats after supplementation with Nigella sativa oil (n-6) may be the result of a direct effect of the oil on the hypothalamus, which in turn increases gonadotrophic realizing hormone $(\mathrm{GnRH})$ where, hypothalamus secretes GnRH, which binds to GnRH receptors on the gonadotropic cells to stimulate the release of FSH and LH into the circulation blood.

Current results indicated that increasing concentration of $\mathrm{PGF}_{2 \alpha}$ by treatment with different sources of oils are in agreement with results reported by Dolatpanah et al., ( 2008) who mentioned that the linoleic acid (C18:2, n-6) is converted to arachidonic acid (C20:4, n-6) which is a precursor for the 2-series of PGs $\left(\mathrm{PGE}_{2}\right.$ and $\left.\mathrm{PGF}_{2 \alpha}\right)$, whereas the linolenic $(\mathrm{C} 18: 3, \mathrm{n}-3)$ acid is converted to EPA (n-3) a precursor of the 3-series of prostaglandins $\left(\mathrm{PGE}_{3}\right.$ and $\mathrm{PGF}_{3 \alpha}$ ). Otherwise, both n-3 and n-6 PUFAs supply the precursors for PGs synthesis and can adjust the expression patterns of many key enzymes involved in both PGs and steroid metabolism (Wathes et al., 2007). Interestingly, PGs and PGF $F_{2 \alpha}$ are known as a key hormone playing an important role in male reproduction. $\mathrm{PGF}_{2 \alpha}$ acts directly on the contractile tissues of the testicular coats and epididymis causing an increased rate of sperm passage from the epididymis to the deferent ducts (Mekonnen et al., 1989). Several experiments in vitro demonstrated that use of $\mathrm{PGF}_{2 \alpha}$ may increase the number of sperm in a collection by enhancing sperm movement from the epididymis to the deferent ducts, where they are available for ejaculation (Shankar et al., 1984) or causes a prolongation of concentration of the testosterone and $\mathrm{LH}$ in bull (Titiroongruang et al., 2011).

The results of this study proved that alters PUFAs significantly $(\mathrm{P} \leq 0.01)$ increases the TAC and decreases MAD in serum of aging bucks after 7 weeks of supplementation. On the other hand, this period of PUFAs supplementation was also associated with increased antiperoxidant activity of the blood serum. 
This result is keeping with those previously reported by Jerzy et al., (2004) who stated that polyunsaturated enhanced antioxidant capacity of boar semen is needed to improve semen preservation. The observed effects in this study also agree with results observed in other species, including boars Strzeżek et al., (2000) reported that the antiperoxidant activity is dependent on the presence of antiperoxidant factors, which may attach to the spermatozoa at ejaculation and can protect them from lipid peroxidative attacks during their passage through the female genital tract. Other studies performed by Mazza et al., (2007) and Mourvaki et al., (2010) reported that supplementation with omega-3 increases the antioxidant activity of seminal fluid, which prevents the oxidation of macromolecules (DNA, proteins and lipids) allows the greater protection of sperm membranes via the inhibited lipid peroxidation and ultimately contributes to a higher quality of semen and in particular increased motility.

\section{Semen quality:}

Data presented in Table 4 summarize the mean values of the reaction time (RT) and classical traits of semen parameters such as ejaculate volume, motility, sperm concentration, abnormal and dead sperms and cell integrity in treated groups with different sources of PUFAs oils. Data revealed that there were significant $(\mathrm{P} \leq 0.01)$ improvements in all mentioned previous parameters in treated groups compared with control. However the Lin and Mix oils groups recorded significant $(\mathrm{P} \leq 0.01)$ highest ejaculate volume, motility of sperm, sperm concentration and cell integrity and significant $(\mathrm{P} \leq 0.01)$ reduction for RT, abnormal and dead sperms compared to other groups. Results show that there were no statistical differences between Ses and Sun oils groups with respect to previous parameter. Interestingly, control group recorded low ejaculate volume, percentage of motility, sperm concentration and cell integrity besides high level of abnormal and dead sperms.

Table 4 showed also groups of rabbit bucks that received different oil sources either separated or combined represented significant $(\mathrm{P} \leq 0.01)$ increase of fertility rate and litter size at birth compared with those for control. However the Lin and Mix oils groups recorded significant $(\mathrm{P} \leq 0.01)$ increase in comparison with other groups. Date show that were no statistical differences between Ses and Sun oils groups with respect to fertility rate, litter size at birth. However, control group recorded significant $(\mathrm{P} \leq 0.01)$ decrease in fertility rate and litter size at birth compared to treated groups. 
Table 4. Effect of unsaturated fatty acids oils on semen quality and reproductive performance for aging buck V-line rabbits.

\begin{tabular}{|c|c|c|c|c|c|c|}
\hline Parameters & Control & Ses & Sun & Lin & Mix & $\begin{array}{l}\text { Sig } \\
\text { test }\end{array}$ \\
\hline \multicolumn{6}{|c|}{ Orally $3 \mathrm{~mL}$ oil/buck/day } & \\
\hline Reaction time (Sec) & $\begin{array}{r}13.9^{\mathrm{a}} \\
\pm 0.25\end{array}$ & $\begin{array}{c}10.8^{\mathrm{b}} \\
\pm 0.12\end{array}$ & $\begin{array}{l}11.23^{b} \\
\pm 0.32\end{array}$ & $\begin{array}{c}9.6^{\mathrm{c}} \\
\pm 0.21 \\
\end{array}$ & $\begin{array}{c}9.7^{\mathrm{c}} \\
\pm 0.22 \\
\end{array}$ & \\
\hline Ejaculate volume (ml) & $\begin{array}{c}0.45^{\mathrm{c}} \\
\pm 0.21 \\
\end{array}$ & $\begin{array}{l}0.52^{\mathrm{b}} \\
\pm 0.24 \\
\end{array}$ & $\begin{array}{l}0.51^{\mathrm{b}} \\
\pm 0.21 \\
\end{array}$ & $\begin{array}{l}0.65^{\mathrm{a}} \\
\pm 0.31 \\
\end{array}$ & $\begin{array}{c}0.69^{\mathrm{a}} \\
\pm 0.26 \\
\end{array}$ & \\
\hline Advanced motility \% & $\begin{array}{l}61.22^{\mathrm{c}} \\
\pm 1.12 \\
\end{array}$ & $\begin{array}{l}75.45^{b} \\
\pm 1.32 \\
\end{array}$ & $\begin{array}{l}73.45^{b} \\
\pm 1.34\end{array}$ & $\begin{array}{l}85.87^{\mathrm{a}} \\
\pm 1.17\end{array}$ & $\begin{array}{l}84.29^{\mathrm{a}} \\
\pm 1.45\end{array}$ & \\
\hline Sperm conc. $x 10^{6}$ & $\begin{array}{c}189^{\mathrm{c}} \\
\pm 10.2 \\
\end{array}$ & $\begin{array}{r}268.2^{b} \\
\pm 13.3 \\
\end{array}$ & $\begin{array}{l}280.4^{b} \\
\pm 15.6\end{array}$ & $\begin{array}{l}312.5^{\mathrm{a}} \\
\pm 16.4 \\
\end{array}$ & $\begin{array}{l}310.3^{\mathrm{a}} \\
\pm 15.7 \\
\end{array}$ & \\
\hline Abnormal sperm \% & $\begin{array}{c}22.3^{\mathrm{a}} \\
\pm 0.82\end{array}$ & $\begin{array}{l}19.21^{\mathrm{b}} \\
\pm 0.45\end{array}$ & $\begin{array}{l}18.31^{b} \\
\pm 0.65\end{array}$ & $\begin{array}{l}12.3^{\mathrm{c}} \\
\pm 0.32\end{array}$ & $\begin{array}{l}11.98^{\mathrm{c}} \\
\pm 0.45\end{array}$ & \\
\hline Dead sperm \% & $\begin{array}{l}29.65^{\mathrm{a}} \\
\pm 0.91\end{array}$ & $\begin{array}{c}26.44^{b} \\
\pm 0.87\end{array}$ & $\begin{array}{c}26.09^{b} \\
\pm 0.91\end{array}$ & $\begin{array}{l}11.92^{\mathrm{c}} \\
\pm 0.77\end{array}$ & $\begin{array}{l}12.17^{\mathrm{c}} \\
\pm 0.34\end{array}$ & \\
\hline Cell integrity \% & $\begin{array}{l}65.78^{\mathrm{c}} \\
\pm 1.25\end{array}$ & $\begin{array}{l}73.22^{b} \\
\pm 1.34\end{array}$ & $\begin{array}{c}71.51^{b} \\
\pm 1.54\end{array}$ & $\begin{array}{l}83.34^{\mathrm{a}} \\
\pm 1.85\end{array}$ & $\begin{array}{l}81.77^{\mathrm{a}} \\
\pm 1.75\end{array}$ & \\
\hline Fertility rate \% & $\begin{array}{l}51.23^{\mathrm{c}} \\
\pm 1.20\end{array}$ & $\begin{array}{l}76.67^{b} \\
\pm 0.88\end{array}$ & $\begin{array}{l}75.10^{\mathrm{b}} \\
\pm 2.08\end{array}$ & $\begin{array}{l}84.12^{\mathrm{a}} \\
\pm 0.98\end{array}$ & $\begin{array}{l}81.34^{\mathrm{a}} \\
\pm 078\end{array}$ & \\
\hline Litter size at birth, $n$ & $\begin{array}{l}5.52^{\mathrm{c}} \\
\pm 0.19\end{array}$ & $\begin{array}{l}7.84^{b} \\
\pm 0.19\end{array}$ & $\begin{array}{l}7.65^{b} \\
\pm 0.39\end{array}$ & $\begin{array}{c}8.9^{\mathrm{a}} \\
\pm 0.70 \\
\end{array}$ & $\begin{array}{l}8.77^{\mathrm{a}} \\
\pm 0.82 \\
\end{array}$ & \\
\hline
\end{tabular}

a,b,c Means within the same row for each effect with different superscripts are significantly different $(\mathrm{P} \leq 0.05)$.

Ses $=$ Sesame oil, Lin $=$ Linseed oil, Sun $=$ Sunflower oil, Sperm Conc. $\times 10^{6}=$ Sperm concentration $\left./ \mathrm{ml} \times 10^{6}\right)$.

$$
\text { * } \quad \mathrm{P} \leq 0.05 * * \mathrm{P} \leq 0.01
$$

Fatty acids such as n-3 and n-6 polyunsaturated fatty acids (PUFAs) are critical nutrients, used to improve male reproductive performance through modification of fatty acid profile and maintenance of sperm membrane integrity, many studies carried out on diets supplemented with PUFAs have demonstrated their capability to sustain sperm motility, viability and fertility (Len et al., 2017). Among the different fatty acid sources, which are rich in PUFAs, plant-derived oils such as Ses, Sun and Lin are considerably significance in improving reproductive performance of buck rabbits due to their high content of essential fatty acids. Vegetable oil has high PUFAs content, especially n-3, n-6 and the appropriate between n-3 and n-6 (Abavisani et al., 2013). 
The previous studies by Retterstol et al., (2001) revealed that human testis has contain a high level of 20 (C20) and 22 (C22) carbon atoms of PUFAs. In context, Poulos et al., (1973) mentioned that PUFAs as phospholipids of mammalian sperm cell membranes characteristically contain very highly proportions of long-chain (C22) PUFAs. In most mammal's, docosahexaenoic acid (DHA, 22:6, n-3) is the dominant PUFAs, although in several species docosapentaenoic acid (DPA, 22:5, n-6) is a major component of the sperm cell membranes. The importance of C22 PUFAs in relation to male fertility has been explain by studies in humans elucidate that the amount of docosahexaenoic acid in spermatozoa is positively correlated with sperm motility (Zalata et al., 1998). Furthermore, Wassall and Stillwell, (2009) reported that PUFAs especially phospholipids is correlated with specific functions in the spermatozoa membrane which causes promotes the creation of micro domains with different fluidity and permeability traits.

Results are in agreement with the observation obtained by Aly et al., (2017) who stated that buck rabbits supplemented with vegetable oils (soybean oil, n-3, sunflower oil, n-6, and mixture with them) had higher sperm concentration, total sperm output, percentage of motile sperms, as well as lower percentages of dead and altered sperm acrosome than the control bucks. Same results obtained by Andreazzi et al., (2004) who showed that rabbits fed a diet containing canola oil, which is rich in omega-3 led to increased sperm concentration, higher semen volume and increased total sperm quantity. Other studies performed by Esmaeili et al., (2012) found that rams dietary higher PUFAs fat levels are important for producing high characteristic semen quality from a quantitative and qualitative aspects. Our results are in harmony with the results reported that diets with an n-6/n-3 fatty acid ratio of $1.6: 1$ could increase the proportion of intact acrosome of the boar's spermatozoa (Rooke et al., 2001). Oils that are rich in n-3 PUFAs also significantly increased sperm density (Blesbois et al., 2004) and sperm number (Estienne et al., 2008). Also, Yan et al., (2013) reported that the development of testis and the morphological structure of spermatozoa in rats were improved with a dietary n-3/n-6 PUFAs ratio of 1.52:1. Moreover, Safarinejad and Safarinejad, (2012) reported that the consumption of unsaturated fatty acids improved sperm antioxidant capacity of infertile men. Interestingly, Zeron et al., (2002) stated that a decreasing in motility and the sperm concentration in ejaculates from aging bulls was accompanied by a decrease in DHA (n-3) proportion in the sperm phospholipids. Also, in agreement with our study by Daraji et al., (2010) higher 
dietary n-6 PUFAs (n-6/n-3=42.94:1) decreased sperm concentration and the number of normal sperm.

On the other hand, lipid composition of the spermatozoa plasma membrane is a considerable determinant of mobility characteristics, and overall viability (Hammerstedt et al., 1990) and membrane integrity (Robinson et al., 2011). It has been known that PUFAs play important role in the sperm membrane fluidity and susceptibility to lipid peroxidation (Stubbs and Smith, 1984). Other results obtained by Rooke et al., (2001) stated that an increase of n-3 and n-6 PUFAs in the pig sperm membrane from diets resulting in improving spermatozoa characteristics. Similar results were found in bovine sperm (Moallem et al., 2015) and ram sperm (Jafaroghli et al., 2014) they demonstrated that the inclusion of PUFAs in diets caused the change of fatty acid composition of sperm membrane and increased the quality of semen. Meanwhile, several studies have focused the probable reasons are due to the variation in type and quantity of dietary fatty acids, especially n-3 and n-6 PUFAs as well as difference in PUFAs composition of semen and spermatozoa in various species. Lipid and fatty acid composition of sperm cells differ not only for different species but also for different animals (Waterhouse et al., 2006). Differences in PUFAs composition of sperm may influence the flexibility and compressibility of the sperm membrane (Neuringer et al., 1988). Such properties may affect the ability of the plasma membrane to accommodate the characteristic flagella motion of the sperm (Castellini et al., 2003). Furthermore, researchers have discovered that the male sperm quality can be affected by the pathway of PUFAs metabolism (Erickson, 1998), oxidative stress (Gaczarzewicz et al., 2003), hormone levels, and physiological function of the epididymis (Esmaeili et al., 2015).

Results in this study revealed that increase of testosterone and PGF $2_{\alpha}$ hormones concentration in treated groups with different sources of PUFAs oils, PGs are related to sperm motility. Also, $\mathrm{PGF}_{2 \alpha}$ is known as a key hormone playing an significant role in male reproduction performance, PGF $2 \alpha$ acts immediately on the contractile cell of the testicular coats and epididymis causing an increased rate of sperm passage from the epididymis to the deferent ducts causes increased ejaculate volume and sperm concentration (Mekonnen et al., 1989) or causes a prolongation of concentration of the LH and testosterone hormones in bull (Titiroongruang et al., 2011). On the other hand, Yan et al., (2016) demonstrated that higher serum testosterone and PGE2 concentrations in the treated groups with ratio n-6:n3, 1:1 improved testis development and superior sperm quality. Also, Castellano et al., (2011) reported that consumed 
fish oils rich in DHA increased the serum testosterone and estradiol levels in boars and improved semen characteristic. Furthermore, Daghistani et al., (2010) demonstrated that dietary fatty acid supplementation altered blood steroid levels and that serum hormone level is related to sperm concentration, motility and morphology (Attia and Kamel, 2012).

Conclusively, it is concluded from the current results that using sesame, linseed and sunflower oils with proper n-6/n-3 fatty acid ratio for aging buck rabbits could play an important role in improvement of semen quality and reproductive performance of aging rabbit bucks.

\section{Acknowledgment:}

Our sincere appreciation and deep gratitude are extended to Dr. Mohamed Elspeiy, Chief Researcher of Rabbit Physiology in APRI for his counsel, great and kind assistance and providing facilities during this study.

\section{REFFERENCES}

Abavisani, A.; Arshami, J.; Naserian, A.A.; Kandelousi, M.A.S. and Azizzadeh, M., (2013). Quality of bovine chilled or frozen-thawed semen after addition of omega-3 fatty acids supplementation to extender. Int. J. Fertil. Steril.; 7:161-8.

Adams, C.E., (1981). Artificial Insemination in the Rabbits: The Technique and Application to Practice. Journal of Applied Rabbit Research, 4:10 -13.

Adibromadi, M.; Najafi, M.H.; Zeinoaldini, S.; Ganjkhanlou, M. and Yousefi, A.R., (2012). Effect of dietary soybean oil and fish oil supplementation on blood metabolites and testis development of male growing kids. Egypt J. Sheep Goat Sci., 7:19-25.

Almiron, I. and Chemes, H., (1988) .Spermatogenic onset. II. FSH modulates mitotic activity of germ and Sertoli cells in immature rats. Int, J. Androl; 11:235-46.

Aly, B.O.; Talaat, M.N.; Sabah, G.; Mostafa, A.A.; Emad, M.S.; Ahmed, A. and Al-Haidary, (2017). Can feed supplementation of the refined vegetable oils enhance the seminal quality of rabbit bucks (Oryctolagus cuniculus). Anim. Reprod., Vol.14, n.4, p.1014-1023.

Andreazzi, M.A.; Scapinello, C.; Moraes, G.V.; Faria, H.G.; Michelan, A.C.; Georg, P.C., (2004). Avaliação da qualidade do sêmenemcoelhos alimentados comraçõescontendo diferentes fontes de óleos vegetais. ActaScientiarum - Animal Sciences, Maringá, Vol. 26, n. 1, p. 87-93. 
Attia, Y.A. and Kamel, K.I., (2012). Semen quality, testosterone, seminal plasma biochemical and antioxidant profiles of rabbit bucks fed diets supplemented with different concentrations of soybean lecithin. Animal. 6:824-33.

Bernardini, M., Castellini, C. and Dal Bosco, A., (1999). Effect of dietary n$3 / \mathrm{n}-6$ ratio on fatty acid composition of liver, meat and pre-renal fat in rabbit. Anim. Sci., 68: 647-654.

Blesbois, E.; Douard, V.; Germain, M.; Boniface, P. and Pellet, F., (2004). Effects of n-3 polyunsaturated dietary supplementation on the reproductive capacity of male turkeys. Theriogenology., 61: 537-549.

Castellano, C.A.; Audet, I.; Laforest, J.P.; Matte, J.J. and Suh, M., (2011). Fish oil diets alter the .phospholipids balance, fatty acid composition, and steroid hormone concentrations in testes of adult pigs. Theriogenology ; 76:1134-1145

Castellini, C.; Lattaioli, P.; Dal bosco, A.; Minelli, A. and Mugnai, C., (2003). Oxidative Status and semen characteristics of rabbit buck as affected by dietary vitamin E, C and n-3 fatty acids. Reprod Nutr Dev., 43: 91-103.

Cherian, G., (2013). Bioactive Food as Dietary Interventions for Liver and Gastrointestinal Disease, Poultry Sci; 92 (2):492-501.

Chibundu, U.C., (2005). Response Of Pre-Pubertal Bucks To Administration Of Estradiol $\beta$. Project Report, Federal University of Technology, Owerri pp. 30.

Correa, J.R. and Zavos, P.M., (1996). Preparation and recovery of frozen thawed bovine spermatozoa via various sperm selection techniques employed in assisted reproductive technologies. Theriogenology, 46: 1225-1232.

Daghistani, H.I.; Hamad, A.W.; Abdel, D.M.; Swaifi, M. and Abu, Z.M., (2010) . Evaluation of serum testosterone, progesterone, seminal anti-sperm antibody, and fructose levels among jordanian males with a history of infertility. Biochem Res Int.; 1:1-8.

Daraji, H.J.; Mashadani, H.A. and Hayani, W.K., (2010). Effect of n-3 and n6 fatty acid supplemented diets on semen quality in Japanese quail (coturnixcoturnix japonica). Int. J. Poult. Sci., 9: 656-663.

Dolatpanah, M.B.; Towhidi, A.; Farshad, A.; Rashidi, A. and Rezayazdi.A., (2008) .Effects of dietary fish oil on semen quality of goats. AsianAustralia's J. Anim. Sci.; 21:29-34.

Duncan, D.B., (1955). Multiple ranges and multiple F. test. Biometrics, 11:42. 
El-Prollosy, A.A., (2012). Effect of photoperiod and the ratio between omega-3 and omega- 6 fatty acids on productive and reproductive performance and immune response of local laying hens. PH.D. Thesis, Fac. of Agric. Damanhour Universty.

Erickson, M.C., (1998). Chemistry And Function Of Phospholipids. Food Lipids, Chemistry, Nutrition And Biochemistry. New York: Marcel Dekker Inc.; p. 41.

Esmaeili, V.; Shahverdi , A.H.; Alizadeh, A.R.; Alipour, H. and Chehrazi, M., (2014). Saturated, omega-6 and omega-3 dietary fatty acid effects on the characteristics of fresh, frozen-thawed semen and blood parameters in rams. Andrologia , 46, 42-49.

Esmaeili, V.; Shahverdi, A.H.; Moghadasian, M.H. and Alizadeh, A.R., (2015). Dietary fatty acids affect semen quality: a review. Andrology, 3: 450-61.

Esmaeili, V.; Shahverdi, A.H.;Alizadeh, A.R.; Alipour, H. and Towhidi, A., (2012). Fatty acid profiles of ram's sperm after removing some fatty acid sources from the diets and persistency of fatty acids in sperm. Int .J . Fertil and Steril, 5:211-216.

Estienne, M.J.; Harper, A.F. and Crawford, R.J., (2008). Dietary supplementation with a source of omega-3 fatty acids increases sperm number and the duration of ejaculation in boars. Theriogenology, 70:70-76.

Gaczarzewicz, D.; Piasecka, M.; Udała, J.B.; laszczyk, B.; Laszczyńska, M. and Kram, A., (2003). Oxidoreductive capability of boar sperm mitochondria in fresh semen and during their preservation in BTS extender. Reprod Biol., ;3:161-72.

Gurr, MI.; Harwood, J.L. and Frayn, K.N., (2002). Lipid Biochemistry: An Introduction. $5^{\text {th }}$ ed Oxford, UK Blackwell Science Ltd.

Hammerstedt, R.; Graham, J.K. and Nolan, J.P. (1990) .Cryopreservation of mammalian sperm: what we ask them to survive. J Androl.; 11:73-88.

Hassan, Manal A., (2012). Studies on Egyptian Sesame Seeds (Sesamumindicum L.) and Its Products 1- Physicochemical Analysis and Phenolic Acids of Roasted Egyptian Sesame seeds (Sesamumindicum L.). World Journal of Dairy \& Food Sciences 7:195-201.

Herbert ,V., (1996) .Prooxidant effects of antioxidants vitamins. J Nutr, 126: $1197 \mathrm{~S}-1200 \mathrm{~S}$.

Ippoushi, K.; Ito, H.; Horie, H. and Azuma, K., (2005). Mechanism of inhibition of peroxynitrite-induced oxidation and nitration by [6]-gingerol. Planta-Medica, 71: 563-566. 
IRRG. International Rabbit Reproduction Group., (2005). Recommendations and guidelines for applied reproduction trials with rabbit does. World Rabbit Sci. , 13, 147-164.

Ismail, Awatif I. and Arafat, S.M., (2014). Quality characteristics of high-oleic sunflower oil extracted from some hybrids cultivated under Egyptian conditions. Journal of Food Technology Research, Vol. 1, P: 73-83.

Jafaroghli, M.; Abdi-Benemar, H.; Zamiri, M.J.; Khalili, B.; Farshad, A. and Shadparvar, A.A., (20140 .Effects of dietary n-3 fatty acids and vitamin $\mathrm{C}$ on semen characteristics, lipid composition of sperm and blood metabolites in fat-tailed Moghani rams. Anim Reprod Sci.; 147:17-24.

Jerzy, S.; Leyland, F.; Magda, K.; Anna, D. and Marek, L., (2004). Effects of dietary supplementation with polyunsaturated fatty acids and antioxidants on biochemical characteristics of boar semen. Society for Biology of Reproduction; Vol. 4, No. 3,271-287

Juma, F.T.; Abdukrahman, H. and Hyfaa, M., (2011). The effects of Nigella sativa oil administration on some physiological and histological values of reproductive aspects of rats. J. Vet. Med., 35 (2):52-60.

Kelso, K.A.; Redpath, A.; Noble, N.H.C. and Speake, B.K., (1997). Lipid and antioxidant changes in spermatozoa and seminal plasma throughout the reproductive period of bulls. Journal of Reproduction and Fertility. 110, 53-59.

Laddha, P. G.; Vidya, G.; Sunil, R.; Bavaskar, N., (2012). Omega-3 fatty acid: Living longer happier from complexities. International Journal of Pharmacy and Biological Sciences; Volume 2, 60-75.

Len Van, T.; Bilal, A.; Sachin, K. and Amrish, K.T., (2017). Polyunsaturated Fatty Acids in Male Ruminant Reproduction. A Review. Asian-Australia's J Anim Sci. 30(5): 622-637.

Lopez, J. and, Alvariño, J.M.R., (2000). Effects of added caffeine on results following artificial insemination with fresh and refrigerated rabbit semen. Anim. Rep. Sci., vol.58, Issues 1-2: pages 147-154.

Luzi, F.; Maertens, L.; Mijten, P. and Pizzi, F., (1996). Effect of feeding level and dietary protein content on libido and semen characteristics of bucks. $6^{\text {th }}$ World Rabbit Congress, Toulouse, 2: 87-92.

Mazza, M.; Pomponi, M.; Janiri, L.; Bria, P. and Mazza, S., (2007). Omega3 fatty acids and antioxidants in neurological and psychiatric diseases: an overview. Progress in Neuro-Psychopharmacology and Biological Psychiatry, Oxford, v. 31, n. 1, p. 12-26, 
Mekonnen, G.; Boland, M. and Gordon, I., (1989). The effect of prostaglandin on semen production and libido in the ram. Ir. Vet. J., 42: 56-9.

Minelli, G.; Zucchi, P.; Luzi, F. and Cavania, C., (1999b). Effect of high dietary vitamins $\mathrm{C}$ and $\mathrm{E}$ administered alone or mixed: influence on rabbit semen characteristics. World Rabbit Sci., 7: 31.

Minelli,G.; Moroni, A.; Castellini, M.; Lattaioli, C.; Mezzasoma, P. and Ronquist, I.G., (1999a). Rabbit spermatozoa: a model system for studying ATP homeostasis and motility. J. Androl., 20 (2): 259-266.

Miros, V.V. and Mikhno, V.I., (1982). Semen quality of male rabbits in relation to age and season. Inst. ZhivotnovodstvaL esotepiiPolesya, 34: 45-48.

Moallem, U.; Neta ,N.; Zeron, Y.; Zachut ,M. and Roth, Z., (2015) .Dietary a-linolenic acid from flaxseed oil or eicosapentaenoic and docosahexaenoic acids from fish oil differentially alter fatty acid composition and characteristics of fresh and frozen-thawed bull semen. Theriogenology.; 83:1110-20.

Mourvaki, E.; Cardinali, R.; Dal Bosco, A.; Corazzi, L. and Castellini, C. (2010). Effects of flaxseed dietary supplementation on sperm quality and on lipid composition of sperm subfractions and prostatic granules in rabbit. Theriogenology, New York, v. 73, n. 5, p. 629- 637.

Neuringer, M.; Anderson, G.J. and Connor, W.E., (1988). The essentiality of n-3 fatty acids for the development and function of the retina and brain. Ann Rev Nutr.; 8:517-41.

Plas, E.; Ber, P.; Hermann, M. andflüger, H.P., (2000). Effects of aging on male fertility. Experimental Gerontology; 35(5): P- 543-55.

Poulos, A. Darin-Beenett, A. and White, I.G., (19730. The phospholipidsbound fatty acids and aldehydes in mammalian spermatozoa. Comparative Biochemistry and Physiology, 46 541-549.

Retterstol, K.; Haugen, T.B.; Tran, T.N. and Christophersen, B.O., (20010. Studies on the metabolism of essential fatty acids in isolated human testicular cells. Reproduction, 121 881-887.

Robinson, J.J.; Ashworth, C.J.; Rooke, J.A.; Mitchell, L.M. and McEvoy, T.G., (2011). Nutrition and fertility in ruminant livestock. Anim Feed Sci Technol.; 126:259-76.

Rooke, J.A.; Shao, C.C. and Speake. B.K., (2001). Effects of feeding tuna oil on composition of pig spermatozoa and in vitro characteristics of semen. $J$. Reprod., 121:315-322. 
Safarinejad, M.R. and Safarinejad, S., (2012) .The roles of omega-3 and omega-6 fatty acids in idiopathic male in fertility. Asian J. Androl.;14:514526.

Santos, J.E.; Bilby, T.R.; Thatcher, W.W.; Staples, C.R. and Silvestre, F.T., (2008). Long chain fatty acids of diet as factors influencing reproduction in cattle. Reprod. Domest. Anim., 43: 23-30.

SAS. (2002). SAS/ STAT User's Guide Statistics. SAS Institute INC., Cary, NC, USA.

Shankar, U.; Benjamin, B.R. and Agarwal, S.K., (1984). Effect of prostaglandin F2 $\alpha$ (PGF2 $\alpha$ ) on reaction time and semen characteristics of buffalo bulls. Ind. J. Anim. Sci., 54: 38-40.

Smith, J.T. and Mayer, D., (1955). Evaluation of sperm concentration by the haemocytometer method. Comparison of four counting fluids. Fertility and Sterility, 6: 271-275.

Strzeżek, J. Fraser, L.; Demianowicz, W.; Kordan, W.W.; Ysocki, P. and Holody, D., (2000). Effect of depletion tests (DT) on the composition of boar semen. Theriogenology, 54 949-963.

Stubbs, C.D. and Smith, A.D., (1984). The modification of mammalian membrane polyunsaturated fatty acid composition in relation to membrane fluidity and function. Biochim Biophys Acta.; 779:89-137.

Surai, P.F.; Noble, R.C.; Sparks, N.H. and Speake, B.K., (2000). Effect of long-term supplementation with arachidonic or docosahexaenoic acids on sperm production in the broiler chicken. J. Reprod. Fertile; 120:257-64.

Swiestra, E.E. and Foote, R.H., (1965). Duration of spermatogenesis and spermatozoa transport in the rabbit based on cytological changes, DNA اين اسم المجلة .411-401

Thatcher, W.W. and Staples, R.C., (2007). Using fats and fatty acids to enhance reproductive performance. Proceedings of the 5th Mid-Atlantic Nutrition Conference. Timonium, MD: University of Maryland; p. 116-29.

Titiroongruang, J.; Hirunpattarawong, P.; Sophonpattana, P.; Singlor, J. and Tummaruk, P., (2011). Effects of prostaglandin F2 $\alpha$ on serum testosterone and semen output in Holstein Friesian bulls in tropical climate. Thai J Vet Med Suppl.; 41:159-60.

Vrablik, T.L. and Watts, J.L., (2013). Polyunsaturated fatty acid derived signaling in reproduction and development: insights from Caenorhabditiselegans and Drosophila melanogaster. Mol.Reprod Dev, 80: 244-259. 
Wassall, S.R. and Stillwell, W., (2009). Polyunsaturated fatty acid-cholesterol interactions: domain formation in membranes. Biochim Biophys Acta. 1788: 24-32.

Waterhouse, K.E.; Hofmo, P.O.; Tverdal, A. and Miller, R.R., (2006). Within and between breed differences in freezing tolerance and plasma membrane fatty acid composition of boar sperm. Reproduction. 131:887-94.

Wathes, D.C.; Abayasekara, D.R.E. and Aitken, R.J., (2007). Polyunsaturated fatty acids in male and female reproduction. Biol. Reprod., 77: 190-201.

Yan, L.; Bai, X.L.; Fang, Z.F.; Che, L.Q.; Xu, S.Y. and Wu, D., (2013). Effect of different dietary omega-3/omega-6 fatty acid ratios on reproduction in male rats. Lipids Health Dis., 12: 33.

Yan, L.;Xu, C.; Jiude, M.; De, W.; Bo, R.; Sheng-Yu, X.; Zheng-Feng, F.; Lian-Qiang, C.; Cai-Mei, W. and Jian, L., (2016). Effects of different dietary n-6/n-3 polyunsaturated fatty acid ratios on boar reproduction. Lipids Health Dis., 15: 31.

Zalata, A.A.; Christophe, A.B.; Depuydt, C.E.; Schoonjans, F.and Comhaire, F.H., (1998). The fatty acid composition of phospholipids of spermatozoa from infertile patients. Molecular Human Reproduction 4 111-118.

Zeron, Y.; Tomczak, M.; Crowe, J. and Arav, A., (2002). The effect of liposomes on thermotropic membrane phase transitions of bovine spermatozoa and oocytes: implications for reducing chilling sensitivity. Cryobiology, New York, 45(2): 143-152. 


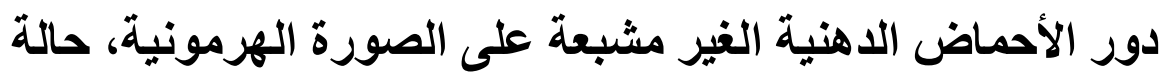

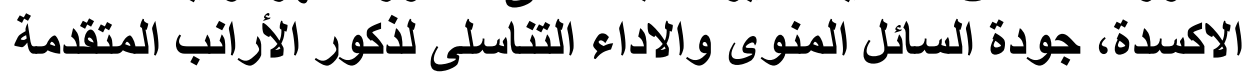
في العمر

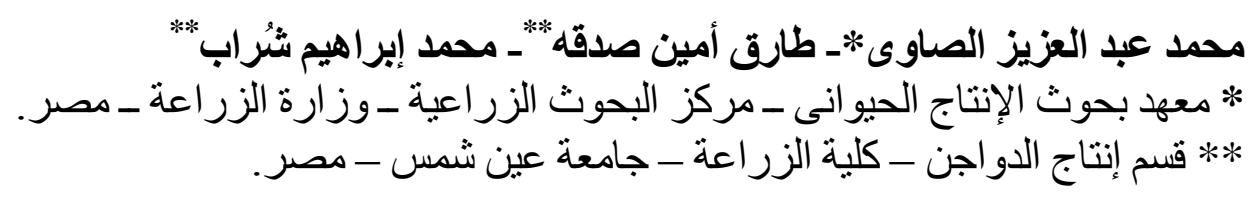

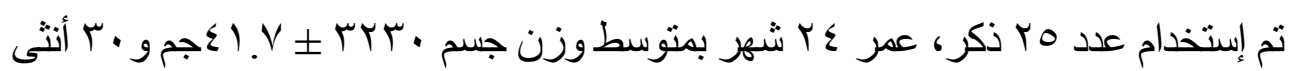

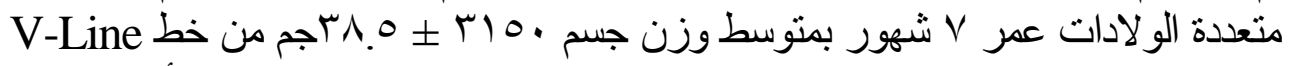

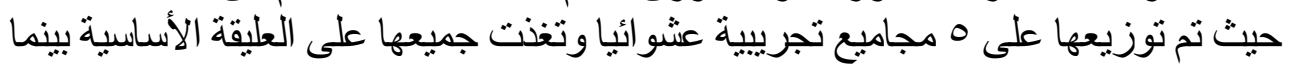

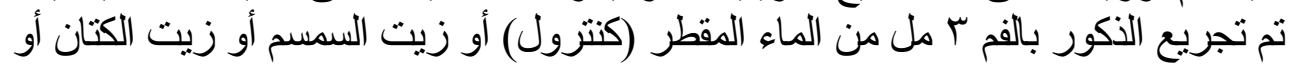

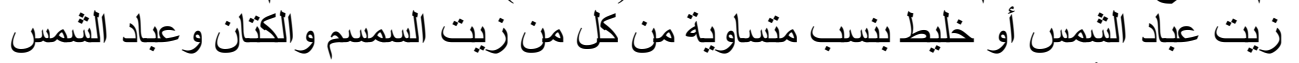

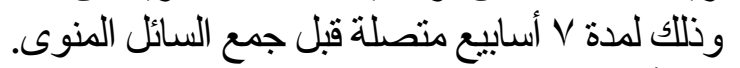
وقل أوضحت النتائج ما لئح:

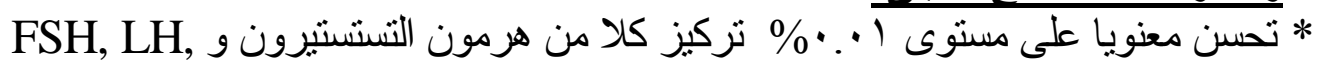

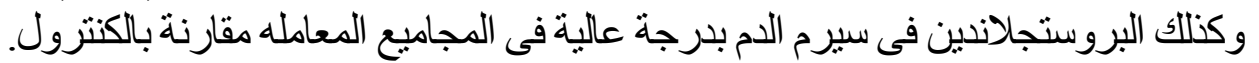

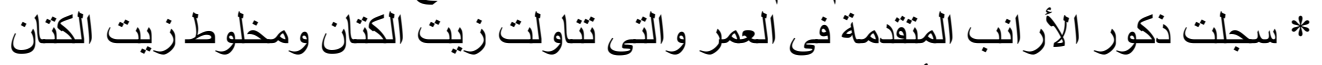

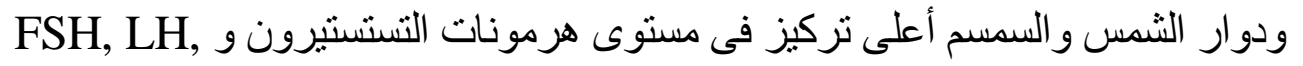
و البروستجلاندين فى سبرم الأدم.

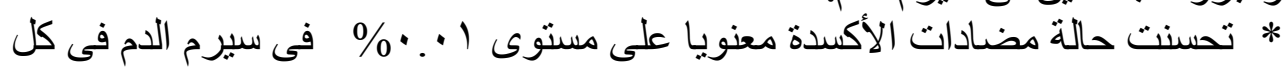

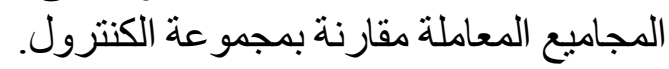

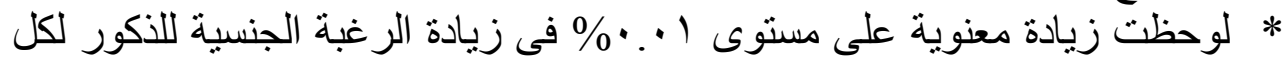

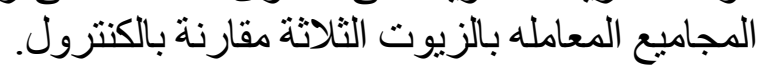

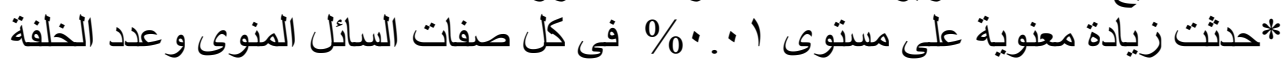

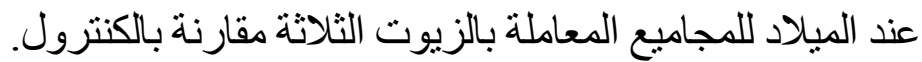

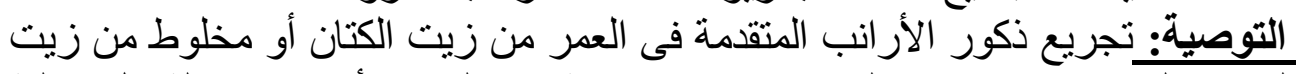

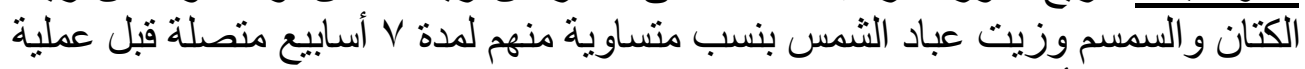

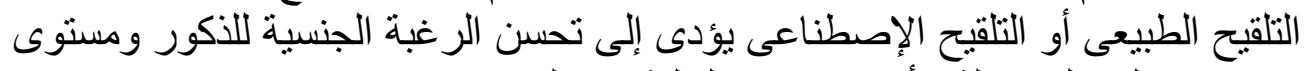
هرمونات التناسل وحالة الأكسدة و عدد الخلفة عند الميلاد. 